\title{
Christopher Polhem and his mechanical alphabet
}

\section{Sigvard Strandh}

\section{OpenEdition}

\section{Journals}

Electronic version

URL: https://journals.openedition.org/tc/844

DOI: $10.4000 /$ tc. 844

ISSN: 1952-420X

\section{Publisher}

Éditions de l'EHESS

\section{Printed version}

Date of publication: 1 March 1988

ISSN: 0248-6016

\section{Electronic reference}

Sigvard Strandh, "Christopher Polhem and his mechanical alphabet", Techniques \& Culture [Online], 10 | 1988, Online since 23 January 2006, connection on 29 September 2022. URL: http:// journals.openedition.org/tc/844 ; DOI: https://doi.org/10.4000/tc.844

This text was automatically generated on 29 September 2022

All rights reserved 
Christopher Polhem and his mechanical alphabet

Sigvard Strandh 